\title{
The expression of follicle-stimulating hormone receptor in ovary and testis
}

\author{
Yuni Ahda*, Purnomo Soeharso ${ }^{\#}$
}

\begin{abstract}
Abstrak
Reseptor follicle-stimulating hormone (FSHR) hanya terekspresi pada sel granulosa ovarium dan sel Sertoli testis. Ekspresinya yang sangat spesifik menunjukkan adanya peristiwa-peristiwa traskripsi khusus pada kedua tipe sel tersebut yang bertanggung jawab untuk aktivasi gen reseptor FSH. Walaupun mekanismenya belum diketahui, namun telah dicapai beberapa kemajuan menyangkut mekanisme yang mengontrol proses transkripsi dan regulasi gen reseptor FSH. Sampai saat ini telah diidentifikasi beberapa elemen regulator penting yang bertanggung jawab untuk proses transkripsi gen reseptor FSH yang tidak mengandung TATA box tersebut seperti elemen E box (CACG(A)TG, -124/-119), elemen GATA (TATC, -88/-85), E2F (TTTCGCG, -45/-39), dan elemen regulator-3 (-197/-171). Studi fungsional menunjukkan bila mutasi terjadi pada elemen regulator tersebut akan menurunkan fungsi promoter secara bermakna dan dampak terbesar terdeteksi bila mutasi terjadi pada elemen E box. Metilasi pada situs CpG spesifik dalam daerah promoter inti tampaknya memegang peranan penting dalam regulasi transkripsi gen reseptor FSH tikus dan mencit. (Med J Indones 2003; 12: 187-93)
\end{abstract}

\begin{abstract}
Follicle-stimulating hormone receptor (FSHR) is exclusively expressed in granulose cells of the ovary and Sertoli cells of the testis. The highly cell-specific of gene expression revealed that transcriptional events unique to these two cell types are responsible for activation of the FSHR gene. Even though its mechanisms are still unclear, several progress regarding the mechanism that control its basal transcription and regulation has been made. It has been identified several important elements that responsible for the transcription of the TATA-less FSHR gene such as: E box element (CACG(A)TG, -124/-119), an inverted GATA (TATC, -88/-85), E2F (TTTCGCG, -45/-39), and regulator element-3 (-197/-171). The functional studies shown that mutations through these regulatory elements significantly decrease the promoter function with greatest impact detected when mutation was done in E-box element. The site-specific CpG methylation within the core promoter seems play an important role in the regulation of rat and mouse FSHR gene expression. (Med J Indones 2003; 12: 187-93)
\end{abstract}

Keywords: FSH receptor, E box element, inverted GATA, E2F, RE-3, methylation

It has been largely known that follicle-stimulating hormone (FSH) is the main hormone to maintain the normal functions of testis and ovary to produce sperms and oocytes in all mammalian species. Decrease concentration of FSH due to either deficient FSH synthesis or secretion cause infertility in male and female. In female, this condition is characterized by abnormal or absence of ovulation. In male, it may lead to infertility due to the production of inadequate numbers of viable spermatozoa. ${ }^{1}$ FSH acts selectively on granulose cells of the follicles and Sertoli cells of the testis through specific receptor (FSHR) on the cell

\footnotetext{
* Biomedical Postgraduate Program, Faculty of Medicine, University of Indonesia, Jakarta, Indonesia

\# Department of Medical Biology, Faculty of Medicine,

University of Indonesia, Jakarta, Indonesia
}

membrane. ${ }^{2}$ Little is known about expression regulation of the FSHR gene in ovary and testis so far. Several studies are still on going in order to find out the mechanisms in detail. In this paper we describe the characterization of FSHR gene and all the knowledge about the regulation of FSHR expression in granulose and Sertoli cells of mammals.

\section{STRUCTURAL ORGANIZATION OF THE FSH RECEPTOR GENE}

FSHR is a member of G-protein coupled receptor subfamily. ${ }^{2}$ The FSHR is divided into three regions: extracellular domain, transmembrane domain and intracellular domain. Restriction analysis of genomic clones and size determination of PCR product reveal FSHR gene is a single copy gene and covers $54 \mathrm{~kb}$ in the human and $84 \mathrm{~kb}$ in the rat. ${ }^{3,4}$ The FSHR gene 
consists of 10 exons and 9 introns. Exon 1 to 9 encodes the extracellular domain while the C-terminal part of extracellular domain, the transmembrane and intracellular domain are encoded by exon 10 . Exon 2 to 8 have the similar length $(68-77 \mathrm{bp})$, amino acid sequence and repeated motif known as a leucine-rich repeat $^{4,5}$ (Figure 1). This motif, which is characterized by a common pattern of aliphatic amino acids sequence (leucine, isoleucine, valine and phenylalanine), also was present in exon 9 but it has the different pattern observed in exon $2-8$. Leucine-rich repeats are involved in cell-cell-specific adhesion and proteinprotein interaction. These repeated units in the FSH receptor are known to be involved in hormone binding. ${ }^{7}$ Interestingly, other member of superfamily of G-protein-coupled receptor such as luteinizing hormone receptor (LHR) and thyroid stimulating hormone receptor (TSHR) also contain this repeated motif. Studies in Sertoli cells or cell lines ${ }^{8-11}$ and transgenic mice ${ }^{12}$ in order to know the structure and activities of the promoter region of the FSHR gene reveal promoter of the FSHR gene is a member of a class of promoter that lack of conventional TATA and CCAAT box. Analysis of the 5'flanking region indicate multiple start sites which are five in human ${ }^{8}$ and two in rat. ${ }^{10}$ Further studies in the promoter of rat and human FSHR promoter reveal no GC box motif, known as the binding site for the Sp-1 transcription factor, and no consensus sequences for either cAMP response elements or activating protein-2 (AP-2) binding sites. The rat FSHR gene has an AP-1 binding site in the promoter region, which is not found in the human or mouse gene, whereas the human FSHR gene has an imperfect 5'half consensus estrogen receptor response element ${ }^{8-11}$ which is not found in other species. All features above are the characteristic of the promoter of housekeeping gene. This feature also detectable in the promoters of LH and TSH receptor gene, ${ }^{13,14}$ although the homology between the core promoter sequences of the three receptor is low. In addition, the presence of several initiator elements (Int) in the promoter region that does not contain TATA motif might be crucial in positioning RNA polymerase II.

Figure 1. Align of gene structures of the glycoprotein hormone receptors. ${ }^{6}$ Exons are depicted as boxes with their number given below and their size in bp given above. Hatched boxes represent leucine-rich repeats and the black boxes, the seven membranespanning domains. 


\section{FSH RECEPTOR TRANSCRIPTIONAL REGULATION}

\section{Transcription factors}

The restricted expression of FSH receptor has brought about scientists interested in studying it mechanisms in detail and to explore the transcription factors involved. Most of the data concerning the expression of the FSHR gene were generated from the evaluation of its promoter in transient transfection assays and transgenic mice. While progress has been made regarding the mechanisms that control basal transcription and regulation by the hormone FSH, the mechanisms that drive cell-specific expression remain elusive. A single response element, called $\mathrm{E}$ box (CACGTG) has been identified for the first time in the promoter of rat FSHR gene at position $-124 /-119 .{ }^{9}$ Functional studies revealed this sequence is required for full promoter function of the rat FSHR gene. A mutation through the $\mathrm{E}$ box had the single greatest impact on rat FSHR promoter activity. Later, it is known that this consensus sequence is present in many mammalian promoter of FSHR gene with a high degree of sequence conservation among them. Except for the human gene which has a single G-to-A change at the first guanosine of the core sequence (5'CACGTG-3' to 5'-CACATG-3') (Figure 2). ${ }^{8,10}$ Studies with the ovine promoter also revealed the important of $\mathrm{E}$ box sequence. ${ }^{15}$ Mutagenesis of both the core and flanking sequence of the $\mathrm{E}$ box shown that a change in the core's central CG dinucleotide (CACGTG) to either GC or GA diminished promoter activity $60-80 \%$ but was tolerated to a greater extent than a change in the core's flanking bases (5'GGTCACGTGACTT-3' to 5'-GtaCACGTGtaTT$\left.3^{\prime}\right) .{ }^{10}$ These studies also showed that the sequence difference within the human $\mathrm{E}$ box had little impact on promoter function (Figure 2). Electrophoretic mobility shift assay (EMSA) identified upstream stimulatory factor 1 (USF1) and USF2, member of the helix-loop-helix family of transcription factor, interact with E-box sequence in cells that express the receptor. ${ }^{16}$ However, USF1 and USF2 are not the specific transcription factor for FSHR expression. This fact arise a question, whether these ubiquitous transcription factor involved in the cell specificity of FSHR gene expression. There is a possibility if they undergo modification in a cell-specific way or may dimerize with a unique protein partner. Recent experiment found that sequence containing an $\mathrm{E}$ box was not only bound by USF protein but also was recognized by orphan receptor chicken ovalbumin upstream promoter transcription factors (COUP-TF orphan receptors). ${ }^{17}$

In vivo genomic footprint analysis in the core promoter using nuclear proteins from Sertoli cells identified other important regulatory elements. They are an inverted GATA (TATC, -88/-85) and an E2F (TTTCGCG, -45/-39). ${ }^{18}$ EMSA showed the presence of one or more sequence-specific proteins interacting with these potential regulatory elements. Antibodysupershift assay as well as competition assay further revealed that testis-specific GATA-1 recognized the inverted GATA element. Transient transfection assays in order to analyze the functional role of the potential cis-acting elements indicating that the GATA and E2F elements required for optimal promoter activity in addition of E-box. Mutation in GATA element decrease the promoter activity to $68 \%$ compared to wild type construct while the mutated E2F binding sequence led to a reduction of promoter activity up to $54 \%$ of wild type. The putative binding motif for transcription factor GATA is conserved in the mouse and rat FSHR promoter but the consensus E2F element is present only in the rat FSHR promoter.

Inspection of the sequence of putative promoter region of ovine FSHR have shown a third regulatory element (RE-3) located at -197 to $-171 .{ }^{17}$ Gel mobility shift and antibody supershift assay demonstrated nuclear factor c-Fos/c-Jun, steroidogenic factor-1 (SF1), upstream stimulatory factor $1 / 2$ (USF-1/2) and chicken ovalbumin upstream promoter transcription factor-1/2 (COUP-TF I/II) potentially bound to RE-3. Functional studies demonstrated USF-1/2, c-Fos/c-Jun and SF-1 were activators, whereas COUP-TFs were repressors.

\section{FSH receptor gene expression}

From the Northern hybridization analysis of FSH receptor mRNA it is known that FSH receptor gene express more than one transcript detectable in testicular and ovarian tissues. The main transcript spans over $2.5 \mathrm{~kb}$ in range and the longer transcript is in the range of $5-7 \mathrm{~kb}$. The normal transcript ( 2.5 $\mathrm{kb})$ is detectable in a variety of species ${ }^{19,20,21}$ although several additional bands could be either observed. It suggests a non species-specific mechanism of FSHR gene expression. Moreover, the pattern of this FSHR transcript is similar in ovarian and testicular tissue. 
Figure 2. Sequence comparison of the rat, mouse, human and ovine FSHR promoter regions. ${ }^{6}$

Aligned sequences of the FSHR promoter regions from rat, mouse, human, and ovine, including the translational start site (+1) and approximately 500 bp upstream. Base positions are indicated in the left margin and are relative to the translational start codon (ATG underline), where adenosine is represented as +1 . Arrows indicate transcriptional start sites identified in each species. DNA elements revealed as important for FSHR regulation are marked with a line over top of the sequence (E2F, Tnr, GATA, E box, and AP1 sites). Asterisks mark cytosines within the rat FSHR promoter that were differentially methylated in nonexpressing and expressing cell types. 
There are some possibilities underlying the generation of different FSH receptor transcripts. The variation is likely due to the use of different transcriptional start sites, or different polyadenylation sites, or due to alternative splicing processes. However, some studies indicated that the use of different transcriptional start sites is not the main mechanism responsible for the generation different transcripts. The generation of different transcripts is more reasonably caused by different polyadenylation sites produces the long transcript $(5-7 \mathrm{~kb})$ and the normal form $(2.5 \mathrm{~kb})$. Furthermore, the alternative splicing processes also contribute to the production of different transcripts. The presence of conserved splice acceptor sites, such as a CAGG nucleotide sequence, may shorten the exons if it is located within the exons or caused incomplete intron splicing. ${ }^{22}$ Splicing events result in a change of ORF, starting with the branch point.

\section{The ovary and testis}

As mentioned above, the expression of FSH receptor is highly cell-specific. In ovary, the FSHR mRNA is located exclusively in granulose cells. Several studies in mouse ovaries revealed the full-length transcripts of FSHR were detected as early as day 5 of postnatal and peaked by day 10 , whereas the shorter transcripts were present on day 1 and three. ${ }^{23,24}$ The increase in all transcripts between day 3 and 5 corresponds to the time when primary follicles are forming, partly as a result of the transformation and proliferation of granulose cells, and the peak transcript levels coincided with the beginning of antral follicle formation. ${ }^{25}$

FSHR expression was also detectable in rat ovaries at the same time. Ranniki et al. ${ }^{26}$ firstly detected FSHR mRNA by Northern analysis in day 7 of postnatal rat ovaries, with the $2.5 \mathrm{~kb}$ transcript predominating. Using RT-PCR, they first detected full-length FSHR mRNA on postnatal day 1 and more clearly from day 5. The mRNA encoding the extracellular domain of the FSHR was amplified two days before the fulllength message was detected, which in turn was detected one to two days before appearance of the FSHR protein. This implies that the expression of functional FSH receptor, required for the acquisition of responsiveness to FSH early in folliculogenesis in the postnatal rodent ovary, depends on a change in alternative splicing rather than a change in gene expression. It can be concluded that FSH action via its receptor is unlikely to be obligatory for initiating growth of primordial follicles. It influence on subsequent development of follicles will depend on the extent to which the full-length receptor is present and connected to the post receptor machinery.

While the mRNA of FSHR exclusively expressed in granulose cells of the ovary, the same transcripts could be found in Sertoli cells of the testis. The presence of the FSHR in rat fetus was identified for the first time at day 17.5. However, this receptor does not response to the FSH yet. This might be due to an immature signal transduction system or a different FSH receptor coupling in the fetus, or it could be a way to avoid premature activation of FSH-stimulated spermatogenesis. ${ }^{1}$

In postnatal mouse the highest level of FSHR expressions are detectable between days 7 and 21 and then turn into lower density between days 20 and 37 . The quite same pattern is found in the rat. The level of FSH receptor mRNA increases until day 7 and then decreases and this level is keep constant until day 20 and decreases rapidly around day 40 . The initial increase is related both to the increase of receptor numbers per Sertoli cells and to the proliferation of Sertoli cells up to day $10 .{ }^{26}$ The decrease expression of FSH receptor in the next day is related to the continuing production of spermatocytes and spermatids as detected by increasing weight of the testis.

\section{Transgenic mice}

Transgenic mice are another studies chosen to help depict the region of the FSH receptor gene required for cell-specific expression. Two separate studies were done by Linder et al. ${ }^{12}$ and Heckert et al. ${ }^{16}$ Five thousand base pair of the rat FSHR promoter were used to drive expression of a reporter gene, either $\beta$ galactosidase or Cre recombinase, in transgenic mice. In the first study, $\beta$-galactosidase expression was measured in various tissues by Northern blot analysis to determine cell-specific expression. ${ }^{28}$ In two separate transgenic lines, evaluation of liver, thyroid, kidney, ovary, and epididymal RNA samples revealed that testis and ovary are the only organ expressed the transgene. The results indicated that tissue-specific expression is directed by the first 5000 bp of FSHR 5, flanking sequence, indirectly suggesting that cell specificity is directed by this gene portion.

In the second studies, Cre recombinase expression was evaluated by reverse transcriptase polymerase 
chain reaction (RT-PCR) of RNA samples collected from various tissues. ${ }^{16}$ A second transgene containing only $198 \mathrm{bp}$ of $5^{\prime}$ flanking sequence was also examined in this study. The results of both transgene revealed the expression of Cre constructs were not exclusively detectable in testis and ovary tissues. Further examination revealed that the expression of the transgene did not follow the same temporal pattern as that of the endogenous FSHR gene. The inaccurate temporal expression of the transgene led to the conclusion that the promoter sequences did not contain enough information to properly restrict or express the receptor to Sertoli cells of the testis and granulose cells of ovary.

\section{Site-specific methylation of FSHR promoter}

Transient transfection assays of FSHR promoter from several species, such as rat, mouse and human are not able to give sufficient information about the specific expression of FSHR. Conversely, the promoter of FSHR could promote transcription of the gene in several cell lines in which the expression of the endogenous FSHR gene was originally repressed. Characterization of the transcription factors involved in the transcription processes of FSHR did not explain the specific expression of the FSHR either. No cellspecific DNA-protein complexes have been found in the FSHR promoter that could mitigate the extreme cell specifically of transcription. However, the Griswold and Kim's study ${ }^{27}$ give an interesting insight of the FSHR specific expression. DNA methylation at $\mathrm{CpG}$ dinucleotide specific in the core promoter of rat and mouse FSHR seems play an important role in the transcription process of FSHR. The core promoter of rat FSHR has seven potential methylation sites while the core promoter of mouse FSHR has four one. The CpG dinucleotides in the rat FSHR promoter were found at nucleotides -155 , $122,-110,-84,-42,-40$, and -20 . Analysis of cytosine methylation pattern within the core promoter region using the sodium bisulfite conversion technique found in all seven cytosine residues in $\mathrm{CpG}$ dinucleotides to be unmethylated in primary cultured of rat Sertoli cells. In contrast, in tissues not expressing FSHR the same region of the gene was methylated at each of the $\mathrm{CpG}$ dinucleotides examined. Some of the methylated cytosine bases were located within major regulatory regions of the promoter such as the E box (CACGTG, nucleotide [nt] -122), the Inr region (-CCGG-, nt -84) and the consensus sequence for transcription factor E2F (TTTCGCG, nt -42 and -40 ). The same analysis was done in DNA from the mouse MSC-1 cells that has been well characterized does not express the FSHR mRNA. It was found four $\mathrm{CpG}$ methylation sites at nucleotide $-161,-121,-84$, and -43 in the mouse FSHR promoter. Three of these sites were found in the major regulatory elements of the mouse promoter including the consensus E box (CACGTG, nt -121), the Inr region (-CCGG-, nt -84$)$, and the E2F (TTTCGCG, nt -43 ).

EMSA analysis showed the site specific methylation of cis-acting regulatory region directly influences the binding affinity of transcription complex to the target sites of promoter. DNA methylation of the E box element (CACGTG, -124/-119) in the FSHR promoter region inhibited the binding of nuclear extracts from Sertoli cells by 3.5 -fold. A methylated $\mathrm{CpG}$ dinucleotide within the Inr region of the FSHR gene in the non-expressing tissue enhanced the binding affinity of additional proteins that were specific for the methylated sequence. Because the Inr element is a central site for the formation of the transcription initiation complex in the TATA-less promoter, the methylated DNA sequence might recruit binding of a methyl-CpG-specific protein and subsequently lead to the repression of the promoter activity. The additional complex showed the presence of $\mathrm{CpG}$ sequence. The same effect also found in the E2F consensus sequence (TTTCGCG). Methylation may decrease binding affinity to this site. Likewise, treatment of MSC-1 cells with 5-azaCdR that has been used to activate silent genes in cells when the expression of that gene is controlled by DNA methylated resulted in the demethylation of the mouse FSHR promoter and reactivated the transcription of the FSHR gene. Altogether, the data presented by Griswold and Kim support the notion that the transcription of the rat or mouse FSHR gene is regulated by methylation or demethylation of $\mathrm{CpG}$ dinucleotide in the proximal promoter.

\section{CONCLUSION}

It is still elusive the restricted expression of FSHR in ovary and testis although several important regulatory elements and transcription factors involved have been identified and characterized. Many studies are still required to explore the specific regulation of FSHR 
expression. However, Griswold and Kim study give a significant insight regarding the exclusive expression of FSHR in rat and mouse testis although this regulation will not be found in human FSHR gene since there are no specific $\mathrm{CpG}$ sites in the core promoter region. Perhaps, in human there is some other mechanism in regulation of specific expression of FSHR gene.

\section{REFERENCES}

1. Simoni M, Gromoll J, Nieschlag E. The folliclestimulating hormone receptor:Biochemistry, molecular biology, physiology, and pathophysiology. Endocr Rev 1997; 18:739-73.

2. Griswold MD, Heckert L, Lindner C. The molecular biology of the FSH receptor. J Steroid Biochem. Mol. Biol 1995;53:215-8.

3. Gromoll J, Pekel E, Nieschlag E. The structure and organization of the human follicle-stimulating hormone receptor gene. Genomics 1996;35:308-11.

4. Heckert LL, Daley IJ, Griswold MD. Structural organization of the follicle-stimulating hormone receptor gene. Mol Endocrinol 1992;6:70-80.

5. Sprengel R, Braun T, Nicolics K, Segaloff D, Seeburg P. The testicular receptor for follicle stimulating hormone: Structure and functional expression of clone cDNA. Mol Endocrinol 1990;4:525-30.

6. Heckert LL, Griswold MD. The expression of the folliclestimulating hormone receptor in spermatogenesis. Recent Prog Horm Res 2002;57:129-48.

7. Kobe B, Deisendorfer J. The leucine-rich repeat: a versatile binding motif. Trends Biochem Sci 1994;19:41521.

8. Gromoll J, Dankbar B, Gudermann T. Characterization of the 5'flanking region of the human follicle-stimulating hormone receptor gene. Moll Cell Endocrinol 1994; 102:93-102.

9. Goetz TL, Lloyd TL, Griswold MD. Role of E box and initiator region in the expression of the rat folliclestimulating hormone receptor. J Biol Chem 1996;271: 33317-24.

10. Heckert LL, Daggett MAF, Chen J. Multiple promoter elements contribute to activity of the follicle-stimulating hormone receptor (FSHR) gene in testicular Sertoli cells. Mol Endocrinol 1998;12:1499-1512.

11. Sairam MR, Subbarayan VSR. Characterization of 5 'flanking region and potential control elements of the ovine follitropin receptor gene. Mol Reprod Dev 1997;48:480-7.

12. Lindner C, Heckert LL, Goetz TL, Griswold MD. Follicle-stimulating hormone receptor gene promoter activity. Endocr J 1994;2:957-66.

13. Kohn LD, Shimura H, Shimura Y, Hidaka A, Giuliani C, Saji M, et al. The thyrotropin receptor. Vitam Horm 1994;50:287-384.
14. Dufau ML, Tsai-Moris CH, Hu ZZ, Buczko E. Structure and regulation of the luteinizing hormone receptor gene. J Steroid Biochem Mol Biol 1995;53:283-91.

15. Xing W, Sairam MR. Characterization of regulatory elements of ovine follicle-stimulating hormone (FSH) receptor gene: the role of E-box in the regulation of ovine FSH receptor expression. Biol Reprod 2001;64:579-89.

16. Heckert LL, Sawadogo M, Daggett MA, Chen JK. The USF proteins regulate transcription of the folliclestimulating hormone receptor but are insufficient for the cell-specific expression. Mol Endocrinol 2000;14:183648 .

17. Xing W, Danilovich N, Sairam MR. Orphan receptor chicken ovalbumin upstream promoter transcription factors inhibit steroid factor-1, upstream stimulatory factor, and activator protein-1 activation of ovine folliclestimulating hormone receptor expression via composite cis-elements. Biol Reprod 2002;66: 1656-66.

18. Kim JS, Griswold MD. E2F and GATA-1 are required for the Sertoli-cells specific promoter of the folliclestimulating hormone receptor (FSHR) gene. J Androl 2001;22:629-39.

19. Gromoll J, Dankbar B, Sharma RS, Nieschlag E. Molecular cloning of the testicular follicle-stimulating hormone receptor of the non-human primate Macaca fascicularis and identification of multiple transcripts in the testis. Biochem Biophys Res Commun 1993;196:1066-72.

20. Robert P, Amsellem S, Christophe S, Benifla JL, Bellet D, Bidart JM, et al. Cloning and sequencing of the equine testicular follitropin receptor. Biochem Biophys Res Commun 1994;201:201-7.

21. Gromoll J, Gudermann T, Nieschlag E. Molecular cloning of a truncated isoform of the human follicle-stimulating hormone receptor. Biochem Biophys Res Commun 1992;188:1077-83.

22. Kelton CA, Cheng SVY, Nugent NP, Schweickhardt RL, Rosenthal JL, Chappel SC, et al. The cloning of the human follicle-stimulating hormone receptor and its expression in COS-7, CHO, and Y-1 cells. Mol Cell Endocrinol 1992;89:141-51.

23. O'Shaughnessy PJ, Marsh P, Dudley K. Folliclestimulating hormone receptor mRNA in the mouse ovary during postnatal development in the normal mouse and in the adult hypogonadal ( $h p g$ ) mouse: structure of alternate transcripts. Mol Cell Endocrinol 1994;101:197-201.

24. O'Shaughnessy PJ, McLelland D, McBride MW. Regulation of luteinizing hormone receptor and folliclestimulating hormone-receptor messenger ribonucleic acid levels during development in the neonatal mouse ovary. Biol Reprod 1997;57:602-8.

25. Findlay JK, Drummond AE. Regulation of the FSH receptor in the ovary. TEM 1999;10:183-8.

26. Rannikki AS, Zhang FP, Huhtaniemi IT. Ontogeni of follicle-stimulating hormone-receptor gene expression in the rat testis and ovary. Mol Cell Endocrinol 1995;107:199-208.

27. Griswold MD and Kim JS. Site-specific methylation of the promoter alters deoxyribonucleic acid-protein interactions and prevents follicle-stimulating hormone receptor gene transcription. Biol Reprod 2001;64:602-10. 
194 Ahda and Soeharso

Med J Indones 